\title{
FENOMENA TRANSAKSI BISNIS ONLINE DI ERA 4.0
}

\author{
Darti Djuharni * \\ Siutama Dewi \\ Sekolah Tinggi Ilmu Ekonomi Malangkuçeçwara, Jalan Terusan Candi Kalasan, Malang \\ *dartidjuharni@yahoo.com
}

\author{
A R T I C L E I N F O \\ Article history: \\ Received May 10, 2020 \\ Revised November 24, 2020 \\ Accepted December 2, 2020
}

Key words:

Transaksi Bisnis, Teknologi, Era

4.0, Fenomenologi

DOI:

https://doi.org/10.33508/jako.v13i1.2509

\begin{abstract}
A B S TRACT
This research aims to find out online business transactions based on the experience of its business people. This study uses a qualitative research type interpretive approach with phenomenology. In this research researchers use several techniques of collecting data trough: Observation, documentation dan interviews. Based on the research results the researchers found some of these things related to the online business as follows: Entrepreneurial motives, entrepreneurial spirit, the importance of innovation in entrepreneurial, dan the importance of building trust dan honesty in entrepreneurship. The researchers contributions in this study are expected to provide information on online business transactions in the 4.0 era based on individual experiences.
\end{abstract}

\section{$A B S T R A K$}

Penelitian ini bertujuan untuk mengetahui transaksi bisnis online yang didasarkan pada pengalaman pelaku bisnisnya. Penelitian ini menggunakan jenis penelitian kualitatif pendekatan interpretif dengan fenomenologi. Dalam penelitian ini peneliti menggunakan beberapa teknik pengumpulan data melalui: Observasi, dokumentasi dan wawancara. Berdasarkan hasil penelitian maka peneliti menemukan beberapa hal ini terkait dengan bisnis online sebagai berikut: motif berwirausaha, semangat berwirausaha, pentingnya inovasi dalam berwirausaha, serta kepentingan membangun kepercayaan dan kejujuran dalam berwirausaha. Kontribusi peneliti dalam penelitian ini diharapkan dapat memberikan informasi tentang transaksi bisnis online di era 4.0 yang didasarkan pada pengalaman individu.

\section{PENDAHULUAN}

Perkembangan bisnis online saat ini menjadi alternatif belanja yang banyak diminati pada era 4.0, dimana transaksi bisnis tradisional beralih ke teknologi digital. Kondisi ini menurut Harisno dan Pujadi (2009) karena penerapan teknologi dapat meningkatkan efisiensi dan memperluas pangsa pasar, sehingga banyak diminati masyarakat terutama ibu-ibu dan mahasiswa.

Jenis usaha yang dilakukan secara online banyak ragamnya, mulai dari produk kecantikan, layanan jasa, produk fashion, jasa rias pengantin dan sebagainya. Berbagai online shop yang marak saat ini antara lain lazada, tokopedia, buka lapak, blibli, elevania, dan shopee (Fitria, 2017). Media untuk melakukan bisnis online dapat dilakukan baik melalui laptop, PC (personal computer), atau gadget. Bisnis online, selain hemat waktu dan praktis, juga banyak mendatangkan keuntungan financial bagi pengguna yang menjalankan bisnis tersebut (Baktiono dan Artaya, 2016). Bisnis online mengubah proses pengembangan, pemasaran interaktif, penjualan, pemesanan, pengiriman, pelayanan, dan pembayaran produk dan jasa yang dibeli lewat internet secara online, juga komunikasi global konsumen secara virtual, menunjang jaringan rekan bisnis sedunia (Yuliana, 2000).

Transaksi pada bisnis online terutama tampak pada kegiatan jual beli mulai dari memperlihatkan adanya kemudahan dalam berpromosi, bertransaksi, pengurangan biaya, mempercepat proses transaksi, peningkatan penjualan, dan kinerja perusahaan, serta sampai pada alasan efisiensi dan efektifitas (Harisno dan Pujadi, 2009).

Beberapa penelitian terdahulu terkait dengan manfaat keuntungan bisnis online yang 
dikemukakan antara lain: (1) Pane dan Sadar (2015) yang menjelaskan bahwa sistem penjualan secara online membantu perusahaan dalam meningkatkan pemasaran, mempermudah dalam melakukan pemeriksaan stok barang dan dalam pembuatan laporan; (2) Hidayaha, Kumaladewi, dan Efryllac (2010) menyebutkan bahwa Sistem Informasi berbasis web dapat memberikan kemudahan bagi para pelanggan dalam melakukan pemesanan tiket pesawat kapan pun dan dimana pun mereka berada serta memberikan informasi jadwal keberangkatan pesawat terbang, sehingga baik pihak Bana Tour maupun pelanggan dapat melihat informasi jadwal keberangkatan tersebut; dan (3) Qomaruddin, Sudradjat, dan Sopdani (2018), menjelaskan bahwa sistem penjualan online memudahkan pembeli untuk melakukan transaksi penjualan dengan tidak perlu mendatangi toko, terutama bagi para pembeli yang memiliki waktu terbatas, dan dapat mengakses transaksi dimana saja dan kapan saja.

Di sisi lain Hasanah (2013) menjelaskan bahwa website E-Commerce mempermudah proses transaksi serta dapat meningkatkan penjualan. Nasution dan Baidawi (2016) menyebutkan bahwa sistem penjualan berbasis web dapat memudahkan customer melakukan transaksi jarak jauh, memudahkan karyawan untuk mengelola laporan karena sudah terkomputerisasi dan secara online, memudahkan pelanggan untuk berbelanja atau melakukan transaksi lain selama 24 jam sehari, memberikan banyak pilihan produk dari beberapa merk, melakukan perbdaningan secara cepat dan pelanggan bisa menerima informasi yang relevan secara real time.

Banyaknya manfaat yang dirasakan oleh pelaku bisnis online sebagaimana diuraikan sebelumnya mendorong peneliti untuk mengkaji lebih jauh kegiatan transaksi bisnis online yang dilakukan masyarakat. Penelitian ini berbeda dengan yang dilakukan oleh Pane dan Sadar (2015) karena mereka menyoroti sistem penjualannya khusus untuk boneka, sedangkan pada penelitian ini difokuskan pada transaksi penjualan yang dilakukan masyarakat untuk segala jenis penjualan. Penelitian ini juga berbeda dengan yang dilakukan Hidayaha, Kumaladewi dan Efryllac (2010), karena mereka memfokuskan pada pemesanan tiket secara online. Selain itu penelitian ini juga berbeda dengan yang dilakukan Hasanah (2013), karena ia hanya meneliti pada Pada Toko Kreatif Suncom Pacitan, dan juga berbeda dengan penelitian yang dilakukan oleh Nasution dan Baidawi (2016).
Berdasarkan hasil penelitian yang diuraikan sebelumnya, peneliti akan mengungkap fenomena bisnis online yang ada saat ini, melalui pengalaman pelaku bisnisnya dengan pendekatan fenomenologi.

Kegiatan bisnis merupakan kajian di bidang akuntansi sebagaimana yang diungkapkan oleh Sawarjuwono (2005) bahwa segala sesuatu yang berkaitan dengan bisnis dapat dikategorikan sebagai kajian akuntansi. Lebih lanjut dikatakannya bahwa kajian akuntansi tidak terbatas hanya pada aspek teknis semata melainkan segala hal yang terkait dengan manusia sebagai pembuat, pengubah, dan pemakai akuntansi. Bahkan Morgan (1988) menyebutkan akuntansi dapat dikatakan sebagai metafora bisnis. Oleh karena itu tujuan penelitian ini adalah mengungkap transaksi bisnis online yang didasarkan pada pengalaman pelaku bisnisnya.

\section{KAJIAN LITERATUR DAN PENGEMBANGAN HIPOTESIS}

Kajian Akuntansi melalui Fenomenologi

Fenomenologi memdanang realitas yang tampak sebagai suatu aktivitas yang dialami (Dwiyoso, Susanto, dan Kaluge, 2008). Lebih lanjut dikatakannya bahwa fenomenologi digunakan untuk memahami makna subyektif individu terkait pada perilaku partisipan. Hal ini sebagaimana dikemukakan oleh Starks dan Trinidad (2007) dalam fenomenologi, realitas dipahami melalui pengalaman yang dialami. Di sisi lain Anggraini (2017) menjelaskan bahwa fenomenologi menggunakan sudut pandang partisipan sebagai informan untuk memahami realitas atau permasalahan secara lebih dekat. Oleh karena itu dalam metode fenomenologi tidak melihat benda melainkan peristiwa yang dialami oleh partisipan (Rachman, 2013), dan juga berupaya mengungkap tentang makna dari pengalaman individu (Harbiansyah, 2008). Fenomenologi berfokus pada penggalian informasi mengenai pengalaman (Putri dan Masykur, 2017) dan keunikan pengalaman hidup serta esensi dari suatu fenomena tertentu untuk memperoleh pemahaman struktur eksistensial, yang bertujuan mendeskripsikan fenomena, dan bukan menjelaskan fenomena (Surdasyah, 2013). Karena itu fenomena hanya dapat diamati melalui orang yang mengalaminya (Asih, 2005). Secara sederhana fenomenologi adalah sebuah studi tentang fenomena dari sudut kesadaran, karena fenomenologi selalu berada dalam kesadaran 
(Sanders, 2001). Dalam proses ini, peneliti mengesampingkan terlebih dahulu pengalamanpengalamam pribadi agar dapat memahami pengalaman-pengalaman subyek yang akan diteliti, karena pendekatan fenomenologi merupakan tradisi riset kualitatif yang berakar pada filosofi dan psikologi serta berfokus pada pengalaman subyek itu sendiri (Berek, 2014). Intuisi dan refleksi secara subjektif dijadikan alat dalam penelitian fenomenologi (Arfiansyah, 2016), dimana terkait dengan penemuan fakta terhadap suatu fenomena sosial dan berusaha memahami tingkah laku individu berdasarkan perspektif partisipan (Syadzwina, Akbar, dan Bahfiarti, 2014).

\section{Konsep Dasar Fenomenologi}

Terdapat beberapa konsep dasar fenomenologi yang perlu dipahami (Hasbiansyah, 2008) antara lain: fenomena, epoche, konstitusi, kesadaran, dan reduksi. Sudarsyah (2013) menjelaskan fenomena termasuk apapun yang muncul seperti emosi, pikiran dan dan tindakan manusia sebagaimana adanya. Hal ini dikemukakan oleh Hasbiansyah (2008) bahwa apa saja yang muncul dalam kesadaran merupakan fenomena. Lebih lanjut fenomena yang hendak kita pahami adalah fenomena kemanusiaan yaitu sebuah fenomena yang kita sendiri ada dalam bagian darinya (Salviana, 2009). Fenomena melibatkan manusia sebagai pelaku aktivitas sosial dalam memahami sebuah makna, diaman tindakan manusia yang melibatkan niat, kesadaran, alasanalasan tertentu dan makna subyektif serta interpretasi yang tersimpan dalam dirinya (Dwiyoso, Susanto dan Kaluge, 2008).

Di sisi lain Amal (2019) menjelaskan fenomena yang tampil dalam kesadaran adalah benar-benar natural dan apa adanya. Epoche merupakan tahapan untuk mencapai essensi fenomena dengan menahan diri untuk menilai sesuatu atau menunda putusan lebih dulu (Amal, 2019). Dalam sikap alamiah dapat diperoleh pengetahuan melalui penilaian terhadap sesuatu terkait dengan cara pdanang lain yang baru, maka dapat menciptakan ide, perasaan, kesadaran dan pemahaman baru (Hasbiansyah, 2008). Konstitusi adalah proses kegiatan dari fenomena yang dialami dalam kesadaran manusia yang dilihat dari sudut pdanang subjek, sehingga kemungkinan akan memberikan makna yang berbeda (Hasbiansyah, 2008). Kesadaran adalah proses bagaimana individu menyadari terhadap suatu fenomena yang dialami (Dwiyoso, Susanto dan Kaluge, 2008).
Dalam memberikan sebuah makna terkait pengalaman yang dialami, dimana fenomena yang ada diantisipasi sebagai sarana untuk merealisasikan diri sebagai kesadaran (Hasbiansyah, 2008) dan reduksi merupakan proses eliminasi terhadap pengungkapan dari hasil transkip wawancara yang tidak jelas, pengulangan kata dan tumpang tindih (Sudarsyah, 2013). Lebih lanjut dikatakannya ekspresi-ekspresi bermakna diberi label dan tema. Inilah yang dimaksud reduksi fenomenologi, dimana peneliti memilah pengalaman dalam mendapatkan fenomena sesuai dengan realita sesungguhnya (Hasbiansyah, 2008), atau bisa juga reduksi fenomenologi transendental, karena hal ini dalam pemahaman fenomenologi peneliti mengesampingkan pengetahuannya seolah-olah untuk pertama kalinya.

\section{METODE PENELITIAN}

\section{Pendekatan Penelitian}

Penelitian ini menggunakan jenis penelitian kualitatif pendekatan interpretif dengan fenomenologi. Pemilihan metode penelitian kualitatif digunakan karena penulis ingin mengungkap hal-hal secara alami dan mencoba menginterpretasi fenomena tersebut (Irianto dan Subdani, 2015). Disisi lain Pendekatan Interpretif digunakan karena peneliti melihat fakta sebagai sesuatu yang unik serta mencari penjelasan tentang peristiwa-peristiwa sosial atau pengalaman orang yang diteliti dalam memahami serta menafsirkan bagaimana realitas sosial yang sesungguhnya (Muslim, 2015).

\section{Fokus Penelitian Fenomenologi}

Fenomenologi tentang sebuah fenomen yang tampak (Dahlan, 2010) dimana peneliti mencari jawaban tentang makna dari suatu pengalaman yang dialami (Hasbiansyah, 2008). Lebih lanjut dikatakannya Pada dasarnya, terdapat dua hal menjadi fokus dalam penelitian fenomenologi yakni:Textural Description dan Structural Description. Teknik pengumpulan data dalam studi fenomenologi adalah wawancara mendalam dengan subjek peneliti (Hasbiansyah, 2008). Pada proses wawancara ini pertanyaan yang diajukan tidak terstruktur, dalam suasana bebas dan memberikan kesempatan untuk mengeluarkan pikiran, serta sudut pdanangnya (Irianto dan Subandi, 2005). Dimana peneliti memberikan pertanyaan dalam bentuk open-ended (terbuka) yang diajukan kepada partisipan agar memberikan jawaban secara terperinci apa yang ingin dikemukakan, sehingga akan memudahkan proses dialog dan membantu 
partisipan menggambarkan pengalamannya secara jelas tanpa ada unsur rekayasa (Creswell, 2015). Lebih lanjut dikatakannya bahwa sering kali pertanyaan yang tertulis akan berubah dan menimbulkan pertanyaan baru selama pengumpulan data, dimana peneliti merekam catatan tentang perilaku partisipan. Di sisi lain Toni dan Lestari (2013) menjelaskan realitas komunikasi dalam pengumpulan data penelitian dihadapkan pada dua metode, yakni: metode direct dan metode natural.

\section{Metode Pengumpulan Data}

Penggunaan fenomenologi dimaksudkan karena peneliti berusaha untuk mengungkap pengalaman individu pelaku bisnis online. Menurut Asih (2005) dan Hasbiansyah (2008), penelitian fenomenologi ditujukan untuk mendeskripsikan makna dari sebuah pengalaman kehidupan, dan memperoleh uraian lengkap sebagai mana fenomena tersebut dialami oleh manusia dalam kehidupannya sehari-sehari. Dalam penelitian ini peneliti menggunakan beberapa teknik pengumpulan data melalui: Observasi, dokumentasi dan wawancara.

Observasi dilakukan melalui pengamatan secara langsung di sekitar lingkungan maupun di media masa. Di sisi lain dokumetasi dilakukan melalui foto-foto, screenshoot terkait dengan pemanfaatan bisnis online sebagai peluang usaha (Syadzwina, Akbar dan Bahfiarti, 2014), sedangkan wawancara dilakukan kepada beberapa informan pelaku bisnis. Pemilihan informan dilakukan terhadap partisipan yang mengalami peristiwa secara langsung dalam hal ini pelaku bisnis online. Informan yang terpilih akan dilakukan wawancara untuk menggali informasi tentang proses bisnis yang dilakukan. Untuk memudahkan dalam penelitian, peneliti menggunakan alat bantu berupa hdanphone untuk merekam semua pembicaraan antara peneliti dan informan kemudian hasil rekaman wawancara diproses dengan harapan akan terbentuknya transkip wawancara dan hasil wawancara. Sebelum menggunakan aplikasi perekam peneliti akan memberi tahu dan meminta izin kepada subyek terlebih dahulu. Analisis data yang peneliti gunakan adalah noema, epoche, noesis, intentional analysis, eidetic reduction (Kamayanti, 2016).

\section{$\underline{\text { Teknik Analisis Data }}$}

Noema menurut Farida (2017) adalah ungkapan awal disampaikan oleh informan penelitian, yang kemudian dijadikan dasar untuk mengupas dan menggali informasi selanjutnya melalui epoche. Menurut Amal (2019) dan Hasbiansyah (2008), metode epoche merupakan langkah-langkah, untuk mencapai essensi fenomena dengan menunda putusan lebih dulu tanpa memberikan benar salahnya, dimana fenomena yang ada benar-benar natural, hal ini memberikan cara pdanang yang sama sekali baru dalam melihat sesuatu, maka dengan epoche kita dapat menciptakan ide, perasaan, kesadaran dan pemahaman yang baru. Bracketing, peneliti harus memahami dan dapat menangkap kata yang mempunyai makna dari sebuah pengalaman untuk dilakukan (Arfiansyah, 2016). Dalam melakukan bracketing peneliti menunda penilaiannya terhadap sesuatu (Hasbiansyah, 2008). Setelah dilakukan bracketing selanjutnya noesis, dimana peneliti terfokus pada kata yang nantinya ditindaklanjuti dengan pendalaman, penggalian makna dalam sebuah pengalaman terkait dengan penelitian, sampai tidak ditemukannya bracketing (Arfiansyah, 2016). Intentional Analysis, peneliti melakukan analisis keseluruhan proses dengan tanpa sentuhan pendapat dari peneliti (Kamayanti, 2016). Eidetic Reduction, proses dimana peneliti mengarahkan diri kepada isi yang paling mendasar dan sejauh mana peneliti melakukan penelitian dari hasil seluruh proses pemaknaan atau sebuah ide yang menjadi dasar dari kesadaran murni (Dahlan, 2010). Lebih lanjut dikatannya penelitian terhadap fenomena dilakukan supaya terungkap hakikat fenomena yang sesungguhnya.

\section{HASIL DAN PEMBAHASAN}

Penelitian ini dilakukan di Malang dan sekitarnya, dengan beberapa orang yang membuka usaha bisnis online baik dari kalangan mahasiswa, ibu rumah tangga, maupun karyawan. Ada lima informan yang peneliti wawancarai, yang tiga berdomisili di Purwosari, sedangkan dua lainnya berdomisili di Malang. Informan pertama (Nia) awalnya tertarik pada bisnis karena hobinya berbelanja online, kemudian ia mencoba melakukan bisnis online karena membutuhkan tambahan uang jajan, kemudian ia mulai mencoba menjadi reseller. Informan kedua adalah seorang ibu rumah tangga (Maya). Sama halnya dengan Nia, ia juga awalnya tertarik karena ada peluang untuk mendapatkan uang tambahan. Ajeng sebagai informan ke tiga adalah seorang mahasiswa yang membuka bisnis denterdiri dari tas, dompet, dan jam tangan pria 
serta wanita. Yang terakhir adalah Chika juga seorang mahasiswa.

Berdasarkan hasil wawancara yang mengacu pada lima informan tersebut, ditemukan beberapa hal terkait dengan transaksi bisnis online yaitu motif berwirausaha, semangat berwirausaha, pentingnya inovasi dalam berwirausaha, serta pentingnya membangun kepercayaan dan kejujuran dalam berwirausaha.

\section{Motif Berwirausaha}

Bisnis online saat ini sedang menjadi trend, karena dapat dilakukan oleh siapa saja, dari kalangan mana saja, serta dapat dilakukan di waktu yang lebih fleksibel. Kondisi ini dijadikan alasan oleh hampir semua informan, karena fleksibilitasnya yang tinggi maka merupakan motif utama dalam menjalankan usaha, seperti diungkapkan oleh Sofi,

“...Kan seperti yang dikatakan kalau sekarang banyak anak muda maupun orang tua, ibu-ibu muda maupun orang dewasa ibu-ibu yang udah berumur semua pakai smartphone, nah kita itu memanfaatkan itu jadi "eehh" dengan sistem penjualan online semakin banyak yang tau dengan produk kita terus semakin besar peluang kita juga dalam memasarkan produk yang kita jual."

Selanjutnya ia juga mengatakan bahwa karena modal yang relative kecil dan tidak terlalu sulit menjalankannya, maka peluang ini pantas untuk dimanfaatkan.

“...nah kita itu nggak harus punya modal sendiri untuk jualan jadi kalau kita udah niat kita cari aja apa yang menurut kita itu cocok sama "eeh" sama diri kita, kalau kita itu suka dalam hal makanan kita bisa coba dimakanan, kalau kita suka difashion bisa coba dalam bidang pakaian, sepatu ataupun tas gitu bisa. Jadi nggak harus kita itu punya modal gitu nggak, pokoknya tergantung pengennya kamu diapa, niatnya apa dibisnis apa, kamu cari dulu lah."

Hal ini dikuatkan pula oleh Chika sebagai berikut, “...Modalnya itu sangatlah sedikit kita cukup daftar member dengan modal Rp 50.000 kita sudah bisa membangun bisnis, selain itu barangnya juga bisa ready stock itu tadi kita tidak perlu stock dirumah mau beli kita tinggal memesankan saja."

Senada dengan apa yang dikatakan oleh Chika, bisnis secara online membutuhkan modal kecil, tetapi juga bisa tanpa modal sudah dapat melakukan usaha, selain itu Maya juga menyatakan,
"...Nggak usah modal, yah kita kan bisa kontak orang lain langsung kita perlu barang ya kita minta dikirimi ya sudah. Misalkan dari supplier mengirim gambar produk maka bisa kita reupload lagi."

Maraknya bisnis online juga dikarenakan adanya pertumbuhan internet yang sangat cepat, sehingga menjadi alasan uga orang untuk menekuni bisnis online. Hal ini seperti dikatakan oleh Sofi :

“...Karena pada era 4.0 ini, banyak sekali dimana perkembangan zamannya itu kita harus mengikuti. Jadi kebiasaan orang sekarangkan memang serba online, serba google, dan internet. Jadi mau tidak mau kita juga harus mengikuti perkembangan industri tersebut."

Promosi terhadap barang yang dijual dapat dilakukan melalui berbagai media sosial seperti Line, whatsapp, facebook, dan instragam. Selain memasarkan barangnya secara sendiri-sendiri melalui media sosial, pemasaran barang dapat dilakukan juga dengan bergabung pada perusahaan-perusahaan yang sudah mapan seperti seperti lazada, tokopedia, buka lapak, blibli, elevania, dan shopee.

\section{Kemudahan/fleksibilitas}

Hampir semua informan menyatakan bahwa bisnis online dapat dilakukan oleh siapa saja karena kemudahan dan fleksibilitas yang tinggi dalam pelaksanaannya, seperti yang disampaikan oleh Ajeng,

“...Yah menarik sih, soalnya kita bisa mengakses dimanapun. kita nggak perlu nyamperin orangnya. kita tinggal pakek hp aja udah langsung bisa milih. Yang penting kita harus tau bahwa bisnis online itu memang terpercaya bukan akun abal-abal."

Nia menyatakan,

"...Menurut saya bisnis online sangat menarik karena tinggal bermain HP sambil tiduran sambil dimana saja dan bisa dilakukan."

Hal senada disampaikan pula oleh Ajeng, "...Sekarang kan sudah canggih sudah ada internet. jadi misalkan kayak mereka mau beli itu salah satu format ordernya kan ada alamat. Nah nati aku tinggal masukin di google aja...Seenggaknya kan nggak mungkin jauh menyimpang dari apa yang ada diinternet"

Chika juga menyatakan,

".....yang paling penting meskipun penjualannya online akan tetapi tidak ada jamnya maka targetkan itu ada jamnya nah seperti kita kayak kerja dikantor muali jam 8 pagi 
sampai jam 4 sore, nah kalau misalnya di rumah kita bisa target untuk 1 hari berapa jam biar apa yang kita inginkan bisa tercapai. misalkan seperti orang-orangkan menyepelehkan bahwa bisnis online bisa ditunda-tunda nah kita jangan seperti itu dimana kita harus mempunyai target dan dijam seperti kerja kantoran."

Begitu juga yang disampaikan Nia,

"...Kalau penjualan offline harus menyediakan tempat toko gitu, kalau online kan tinggal upload-upload, duduk manis, bubuk. Itu yah tinggal upload-upload kan nanti ada yang minat nah kalau offline itu nggak enaknya barangnya habis beli jadi uangnya itu nggak kelihatan, maksudnya 'eeh' buat kayak buat beli-beli barang terus. Ya sama-sama dapat keuntungan tapi kalau offline itu buat beli barang yang ditokonya itu."

Maya mengatakan,

"... karena waktunya lebih fleksibel, waktunya kita lebih bisa mengatur sendiri, kita bisa mengefektifkan sendiri sesuai dengan keinginan kita."

\section{Niat dan Keyakinan}

Melakukan bisnis secara online dapat dipengaruhi oleh 2 faktor yaitu niat dan keyakinan, yang mana dapat mempengaruhi pemikiran seseorang dalam melakukan bisnis, hal tersebut mampu untuk mendorong kita terus maju dan berusaha, karena hanya kita sendiri yang bisa memotivasi diri bukan orang lain. Biasanya orang yang mengalami kebingungan, karena niatnya kurang ditumbuhkan pada dirinya, yang mana dalam membuka suatu usaha banyak masalah yang akan muncul. Seperti yang dikatakan oleh informan Nia sebagai berikut,

"... pasti orang sukses itu berturut-turut ada masalah ini itu ada kendalanya nggak mungkin lurus langsung sukses gitu, kendala misalkan semangat yang turun karena peminatnya dikit terus orangnya pasti jarang upload-upload foto yang dijual tersebut."

Selain yang dikatakan Nia Amalia terkait banyaknya masalah yang muncul, pelaku bisnis juga bisa mengalami titik jenuh seperti kebosanan atau kemalasan yang muncul pada diri mereka.Hal tersebut bisa dilakukan dengan kembali lagi ke niat awal atau tujuan kita dalam membuka usaha ini, yang mana niat awal kita harus dipegang kuat. Hal ini sebagaimana yang dikatakan informan kelima yaitu Chika sebagai berikut,
"...Niat awal itu harus dipegang kuat."

Niat merupakan salah satu hal yang perlu ditumbuhkan dalam diri kita, yang mana bisa mempengaruhi tindakan dalam berwirausaha terkait dengan penjualan produk. Bisa jadi apabila kita malas maka penjualan kita akan turun, secara otomatis pendapatan kita juga turun, maka perlu adanya hal-hal yang diketahui sebelum membuka usaha. seperti petikan hasil wawancara dengan Nia sebagai berikut,

“... Dimana yaitu (1) Fokus pada satu bidang terlebih dahulu (2) Memilih produk apa yang akan dijual/dipromosikan yang sudah di kuasai, jika tidak maka ada pelanggan bertanya tentang produk apa itu jika kita tidak tahu sama saja pelanggan tersebut akan lari ke market online lainnya. (3) Membuat lapak online. (4) Melakukan pemasaran dengan cara memposting barang dan mencari reseller sebanyak mungkin"

Hal senada disampaikan juga oleh Maya,

"... Niat, kemudian putuskan apa yg ingin dijual, promosikan bisa melaui wa."

Chika mengatakan,

“... Niat karena kalau menurutku gagal itu karena dia itu kurang akan niatnya."

Selain niat yang perlu ditumbuhkan, hal lain yang perlu diperhatikan adalah keyakinan. Hal ini karenabisa mempengaruhi diri pelaku bisnis dalam pengambilan keputusan terhadap usahanya terkait motif berwirausaha.Dalam membuka usaha bisnis online tidak semudah yang kita fikirkan, banyak masalah yang muncul maka harus disertai dengan usaha, kerja keras, jangan pernah putus asa dan selalu berjuang. Seperti yang dikatakan oleh Ajeng sebagai berikut,

“... Kalau misal dari diri kita pribadi dari internal kita "apa ya" yang penting itu yakin, kemudian juga jangan putus asa karna kan pastinya dalam membuka suatu usaha kan nggak semuanya instan, nggak semuanya kita bisa langsung ngedapetin pasaran yang "apa ya" kayak pembeli tetap kayak gitukan nggak bisa, pastinya ada tahap-tahap yang harus kita lewatin, nah tahap-tahap itu kan juga nggak mudah."

\section{Semangat Berwirausaha}

Semangat dalam menjalankan usaha bagi masing-masing pelaku bisnis memiliki stdanar yang berbeda-beda. Sifatnya bisa berubah dari waktu ke waktu, kadang naik ataupun turun. Bisa jadi kemarin semangat tinggi, hari ini menjadi langsung down atau turun, lalu besoknya mulai 
bangkit kembali, yang mana hal tersebut bisa terjadi pada pelaku bisnis yang mengalami titik jenuh seperti kebosanan atau sudah tidak bersemangat lagi dalam usahanya, maka disitulah kita harus bisa pdanai-pdanai dalam mengatasi permasalahan yang terkait dari dalam diri kita sendiri. Hal tersebut bisa dilakukan dengan kembali lagi ke niat awal kita dalam membuka usaha ini. Hal ini sebagaimana yang dikatakan informan kelima yaitu Chika sebagai berikut,

“... aku sendiri dimana aku mengalami titik jenuh dibisnis online ini, dimana tidak ada yang beli akan tetepi kita sendiri sudah semangat. tapi hal itu balik lagi ke niatku awal ingin namanya nanti kita menjadi ibu rumah tangga ingin tetap ada keuntungan yang dihasilkan dan gimana kita sendiri bisa mengelolah titik jenuh itu tadi. Niat awal itu harus dipegang kuat."

Selain yang dikatakan oleh Chika terkait mengingat kembali niat awal untuk menumbuhkan semangat, lain halnya dengan orang-orang yang mengalami semangat yang turun, karena dari pelaku bisnisnya sendiri jarang update produk yang dijual sehingga akan menyebabkan peminatnya sedikit. Seperti yang dikatakan oleh informan pertama yaitu Nia Amalia sebagai berikut,

“... pasti orang sukses itu berturut-turut ada masalah ini itu ada kendalanya nggak mungkin lurus langsung sukses gitu, kendala misalkan semangat yang turun karena peminatnya dikit terus orangnya pasti jarang upload-upload foto yang dijual tersebut."

Apalagi usaha yang dilakukan masih dibilang baru, yang mana kita harus pdanai-pdanai dalam mendapatkan hati pelanggan. Sebagaimana yang dikatakan oleh informan ketiga yaitu Ajeng,

“... eehh awal kita mulai itu pasti ngerasa kok jualanku nggak ada yang beli sih kayak gitu, nah hal-hal kayak gitu kan wajar dalam suatu usaha apalagi kalau kita baru buka usaha, jadi ya gimana cara kita buat ngedapetin pelanggan itu promosi kita harus kita gencarkan."

Dalam meningkatkan semangat beraktivitas kita juga harus tahu keinginan, harapan, tujuan dan cita-cita, karena dalam menjalankan bisnis ini bukanlah hal yang mudah, banyak sekali rintangan dan permasalahan lain yang dapat menghiasi perjuangan seseorang terkait kerja keras dan usaha yang kita lakukan. Selain kerja keras sangatlah membutuhkan perjuangan, semangat tinggi dan tekad kuat serta tidak gampang putus asa, yang mana faktor dari dalam diri kitalah yang mampu menumbuhkan semangat berwirausaha. Seperti yang disampaikan oleh Ajeng,
“.. harus semangat dan nggak boleh putus asa kan karena kalau yang namanya awal membuka usaha pastinya kan ada aja tuh yang namanya misalkan sepi dipasaran, kurang bisa ngedapetin hati pelanggan, yang penting nggak gampang nyerah. Yang terpenting gimana caranya bisa tetep konsisten sama bisnis yang kita jalani. Terus nggak boleh down misalkan kita melihat bisnis online yang lain lebih berkembang dari pada bisnis online kita, dimana rezeki orang kan sudah diatur. Yang penting sudah melakukan usaha yang terbaik.Pokok intinya yakin sih dan semangat."

Dari pengalaman lima informan yang diwawancarai bahwa dalam berwirausaha tentunya semangat sangatlah diperlukan bagi pelaku bisnis, yang mana menjadi salah satu faktor sukses dalam mejalankan usaha. Dengan demikian seorang pelaku bisnis harus memiliki semangat yang tinggi sehingga dapat mendorong kelancaran bisnisnya. Semangat kerja berhubungan erat dengan kegairahan kerja, yang mana kesenangan yang lebih mendalam terhadap pekerjaannya sehingga akan lebih bergairah terkait pekerjaan akan lebih cepat dan tidak mudah lelah, karena adanya rasa senang bukan susah. Kegairahan untuk mengerjakan suatu pekerjaan karena ada unsur kecintaan, passion, kesukaan dan hobi didalamnya.

Selain kegairahan dapat juga dengan mengingat kembali ke niat awal dalam membuka usaha, yang mana hal tersebut dapat mempengaruhi semangat kita. Karena niat awal merupakan suatu hal yang harus dipegang kuat supaya tetap bersemangat. Kemudian support dari lingkungan sekitar yang dapat mempengaruhi semangat kita, yang mana faktor lingkungan yang mendukung dapat memungkinkan peningkatan penjualan dan memungkinkan peminatnya menjadi banyak. Sehingga hal tersebut bisa dapat meningkatkan semangat kita. Selain support dari lingkungan sekitar, kita juga harus menumbuhkan kerja keras, tekad kuat, serta tidak gampang putus asa.

\section{$\underline{\text { Inovasi }}$}

Bisnis yang telah dijalankan, apapun bentuknya perlu diupayakan agar tetap bisa berlanjut dan tidak dapat berhenti sebagaimana ungkapan para informan.Salah satu upaya yang perlu dilakukan adalah mencari sesuatu yang baru (inovasi) sehingga konsumen merasa tertarik dan mau membeli produk yang dipasarkan.Terkait inovasi, beberapa informan mengungkapkan pengalamannya sebagai berikut. 
Ajeng mengatakan, "..... menurut aku kyak kalau jual snack bouqet aja itu kyak "apa ya" ngerasa kurang berinovasilah akhirnya dari situ aku coba-coba ..."apa ya" terus ada inovasi gitulah...ya mungkin ada yang dikasih bunga kecil-kecil gitu nah aku pengennya bunga yang apa ya bunga itu ya juga kelihatan menonjol gituloh, "eehh" jadi kan kayak apabila kita berinovasi kemudian promosinya gencar pastinya kan "eehh" orderanorderan itu juga akan berdatangan kayak gitu."

Selain dari sisi produknya, inovasi dapat dilakukan melalui jalur pemasarannya seperti yang disampaikan oleh Sofi,

" ...eeehh bisa pakai promosi terus kalau ada event bazar-bazar kita juga ngikuti, tapi kalau untuk bazar masih belum ya tapi ada rencana kalau mau ada bazar gitu mau ikutan supaya lebih banyak lagi yang ngenal jimshoney. Jadi "eeh" buka diakun sosial media yang lain shoppe misalnya itu juga bisa meningkatkan penjualan, terus promosi itu ngenak banget juga, terus juga mintabantuin temen itu juga bisa."

Promosi merupakan salah satu inovasi yang sering dilakukan oleh pelaku bisnis untuk meningkatkan penjualan mereka. Pelaku bisnis biasanya membuat agenda kapan harus melakukan promosi, karena apabila kita menunda sehingga pekerjaan akan menumpuk dan hasilnya kan merugikan kita sendiri. Jadi hal terpenting dalam melakukan promosi dipenjualan online adalah menjadwalkan jam promosi. Seperti yang dikatakan oleh Chika berikut ini,

“... hal satu yang paling penting meskipun kamu penjualannya online akan tetapi tidak ada jamnya maka targetkan itu ada jamnya nah seperti kita kayak kerja dikantor muali jam 8 pagi sampai jam 4 sore, nah kalau misalnya di rumah kita bisa target untuk 1 hari berapa jam biar apa yang kita inginkan bisa tercapai. misalkan seperti orang-orangkan menyepelehkan bahwa bisnis online bisa ditunda-tunda nah kita jangan seperti itu dimana kita harus mempunyai target dan dijam seperti kerja kantoran."

Inovasi bisnis juga bisa dari layanan yang dapat memenuhi kebutuhan konsumen, yang mana merupakan suatu hal yang harus diperhatikan oleh pelaku bisnis dalam memberikan kepuasan kepada konsumen. Sebagian besar pelaku bisnis tidak memperhatikan pelayanan yang diberikan ke konsumen, maka pelaku bisnis dituntut untuk lebih kreatif dan inovatif. Menciptakan budaya inovatif seperti memberikan kenyamanan kepada pelanggan, komunikatif, dan, ramah. Sebagimana dikatakan oleh Nia,

“... jika pelanggan saya berminat produk saya, mereka akan chat saya diinstagram maupun di whatsapp. Saya akan melayaninya sebaik mungkin semaksimal mungkin agar mereka nyaman berbelanja dimarket online saya."

Hal ini diperkuat oleh Ajeng,

"...Intinya sih kita harus ramah sama pelanggan, terus harus komunikatif. intinya kita berusaha semaksimal mungkin buat memuaskan pelanggan."

Begitu juga Sofi menyampaikan hal yang senada, "...kita melayani pelanggan sebisa mungkin ramah dan apapun pertanyaannya dari konsumen kemungkinan besar kita harus bisa menjawab. Jadi biasanya customer-customer itu tanya tentang harga, produk, dimana kita harus bisa menjawab pertanyaan mereka."

Pelayanan sangat berkaitan dengan kepuasan pelanggan. Pelayanan dapat dikatakan memuaskan apabila pelayanan tersebut dapat memenuhi kebutuhan dan harapan pelanggan, yang mana apabila pelanggan merasa tidak puas terhadap suatu pelayanan yang disediakan, maka pelayanan tersebut dapat dipastikan tidak efektif dan efesien. Jika hubungan yang dilakukan sudah baik dalam kurun waktu yang lama maka tak heran akan timbul loyalitas oleh konsumen pada bisnis kita, yang mana akan memberikan tempat tersendiri dihati konsumen. Oleh karena itu yang pasti diingat bahwa untuk membuat perubahan dan perkembangan dalam bisnis diperlukan cara yang memang belum pernah dilakukan sebelumnya misalkan berupa tampilan bisnisnya, yang mana dalam melakukan usaha harus berbeda dengan yang lain agar pelanggan tertarik dengan apa yang kita jual yaitu dengan mendesain produk semenarik mungkin misalnya menggunakana aplikasi software coreldraw, photoshop, dan aplikasi lain yang bisa digunakan untuk mengedit atau bisa juga melakukan sesi pemotretan produk dengan pengaturan cahaya yang bagus, dan kamera yang canggih, akan tetapi yang lebih pentingnya lagi yaitu foto produk sesuai dengan bentuk fisik.

\section{Kepercayaan dan Kejujuran}

Menjaga kepercayaan dari para pelanggan merupakan suatu keharusan apalagi bagi sebuah penjualan online yang cara operasionalnya sangat berbeda dengan penjualan offline biasa. Di karenakan beberapa situasi diantaranya, penjual dan 
pembeli tidak dapat bertemu secara langsung, pelanggan tidak dapat melihat langsung produk yang dijual serta proses pembayaran yang harus melalui transfer bank atau sistem pembayaran online. Dalam mejalankan bisnis baik itu offline maupun online, kepercayaan pelanggan menjadi salah satu aspek suksesnya sebuah bisnis. Namun kenyataannya mendapatkan hingga meningkatkan kepercayaan dari pelanggan bukan sesuatu yang dapat diraih secara cepat, yang mana dalam bisnis online bisa dilakukan dengan memberikan penawaran harga yang wajar, yang mana kualitas sesuai dengan harga.

“...Yang penting kita harus tau bahwa bisnis online itu memang terpercaya bukan akun abalabal." (Ajeng).

Meningkatkan kepercayaan dapat dilakukan dengan mendeskripsikan keadaan barang yang kita jual secara jelas mulai dari harga barang, model, ukuran, bahan yang digunakan, warna yang tersedia, dan lain-lain, yang mana deskripsi atau bisa disebut dengan caption yang dapat digunakan secara singkat, jelas, dan padat serta tidak mengdanung kalimat yang bertele-tele yang membuat pelanggan malas untuk membacanya. Informasi tidak hanya dari deskripsi produk yang dijual, bisa juga tambahan informasi diberikan dengan salah satu cara yaitu memberikan testimoni. Testimoni dari pelanggan sebaiknya dikumpulkan secara khusus dan mudah diakses oleh calon pelanggan yang lain, misalkan di instagram membuat snapgram kemudian bisa disimpan dan mencantumkan testimoni pada akun bisnis yang kita buat atau bisa dengan mengirim testimoni di grup whatsapp serta dapat di kirim langsung ke calon pelanggan. Di samping itu salah satu hal yang tidak dapat dipisahkan dari dunia bisnis, apalagi secara online adalah masalah pembayaran. Sekarang ini pelaku bisnis cenderung melakukan transaksi dengan memanfaatkan transfer via ATM, bahkan cash on delivery.

Kepercayaan masyarakat juga akan tumbuh apabila penjual memahami betul atas barangbarang yang dipasarkan, karena beberapa pelanggan sebelum memutuskan untuk membeli akan menanyakan beberapa hal yang ingin diketahuinya. Selain itu ketepatan waktu pengiriman barang merupakan hal yang sangat didambakan, karena banyak keluhan konsumen terkait dengan waktu pengiriman yang cukup lama, sehingga mengecewakan pelanggan. Kepercayaan merupakan dasar dalam melakukan bisnis secara online, yang mana pelaku bisnis juga menaruh kepercayaan didalam dirinya terhadap konsumen, apabila kita menaruh kecurigaan yang berlebihan maka akan menimbulkan permasalahan pada diri sendiri.

Karena dengan dimulainya kepercayaan pada diri sendiri, hal itu juga akan mempengaruhi dengan usaha yang kita lakukan. Hal tersebut sebagaimana yang dikatakan oleh informan keempat yaitu Sofi Faulana M dalam hasil wawancara sebagai berikut,

“.... Kalau kita bisnis online berdasarkan kepercayaan.Apabila Kalau kita bisnis online menaruh kecurigaan berlebihan itu membuat kita kesulitan sendiri.jadi kalau kita bisnis online kita harus merasa yakin dan percaya seperti itu. jadi percayanya ini kepada customer kalau mereka memang benar-benar ingin memesan produk kita. Pasti mereka serius akan benar benar memesankannya dan mereka yakin seperti itu. Dan segera transfer sejumlah uang yang sudah ditentukan."

Selain membangun kepercayaan dalam berbisnis maka kejujuran juga diperlukan dalam membuka suatu usaha. Ketika sikap jujur menjadi dasar dalam berbisnis terutama bisnis online, maka kita akan melihat respon konsumen terkait sikap jujur yang diterapkan, yang mana apabila kita mengambil foto dari hasil orang lain akan tetapi kita sendiri tidak dapat melakukannya, maka bisa jadi akan mengecewakan pelanggan kita, sehingga akan menjadi permasalahan pada usaha kita, oleh karena itu hal yang terpenting adalah jangan sampai membohongi pelanggan. Seperti yang dikatakan Ajeng sebagai berikut,

"...kalau bisa itu jangan sampai kita ngebohongin pelanggan entah itu kita nyomot gambar dari orang lain biar kelihatan bagus. padahal sebenernya kita nggak mampu memberikan hal tersebut kepada pelanggan."

Kejujuran juga perlu diterapkan saat melakukan pengiriman barang, misalkan ketika ada kendala dalam proses pengiriman barang, maka katakan kepada pelanggan bahwa barang belum dikirim dan pastikan untuk memberikan kepastian kapan barang tersebut dikirim, yang mana kita sebagai pelaku bisnis harus jujur dalam bersikap. Kemudian kejujuran terkait produk yang dijual harus benar-benar sesuai dengan bentuk fisiknya atau produknya original sehingga hal tersebut tidak menjadi kekecewaan pelanggan. Seperti yang dikatakan oleh Maya sebagai berikut,

"... Ya kita harus menjadi penjual yang amanah,

kita harus menjual produk-produk yang original nggak menipu pelanggan gitu aja."

Kejujuran merupakan salah satu dalam memuaskan pelanggan, yang mana apabila terjadi 
suatu masalah yang ada terkait dengan penjualan produk, maka katakanlah dengan jujur hal itu akan membuat hati pelanggan akan merasa tidak dikecewakan. Seharusnya sebisa mungkin kita jaga mereka agar mereka juga setia kepada kita, sebagimana kita bisa memberikan informasi produk misalkan dari segi harganya, yang mana dapat mencantumkan sesuai dengan apa yang sudah tertera seperti yang dikatakan oleh Chika,

“... harga produk dikatalog segini, terus kita tinggikan harganya terus didiskon harganya tiduk tidak diperbolehka. Oriflame itu harus sesuai real benar-benar ada diharga katalog tidak boleh ditinggikan meskipun dikurangi atau diturunkan harganya juga tidak boleh harus benar-benar real harga katalog.Dimana itu merupakan strategi kita biar bisnis kita semakin berkembang."

Dalam menjalankan bisnis baik itu offline maupun online, kepercayaan pelanggan menjadi salah satu aspek suksesnya sebuah bisnis. Menjaga kepercayaan dari para pelanggan merupakan suatu keharusan apalagi bagi sebuah penjualan online yang cara operasionalnya sangat berbeda dengan penjualan offline biasa. Namun kenyataannya mendapatkan hingga meningkatkan kepercayaan dari pelanggan bukan sesuatu yang dapat diraih secara cepat, yang mana dalam bisnis online bisa dilakukan dengan memberikan penawaran harga yang wajar. Bisnis online bisa dilakukan dengan memberikan penawaran harga yang wajar. Harga yang wajar maksudnya jangan memberikan harga yang terlalu murah ataupun mahal, apabila harga terlalu murah akan berdampak pada bisnis kita. Karena seperti yang kita tahu saat ini bahwa apabila produk yang dijual murah maka konsumen akan berfikir usaha tersebut merupakan penipuan atau jangan terlalu tinggi juga dalam menentukan harga karena akan menyebabkan permasalahan pada diri kita sehingga kita tidak bisa bersaing dengan pelaku bisnis lainnya, yang mana kualitas sesuai dengan harga. Selain penawaran harga dalam membangun kepercayaan dapat dilakukan dengan memberi alamat toko dan kontak yang jelas, yang mana dapat dicantumkan disetiap akun media yang kita punya misalkan di whatsapp, Instagram, facebook, shopee dan lain sebagainya, supaya pelanggan percaya bahwa bisnis tersebut benar-benar ada bukan abl-abal. Kemudian memberikan deskripsi produk sesuai dengan bentuk fisik, satu hal yang perlu diingat jangan sampai membohongi pelanggan.

Selanjutnya dapat juga dengan memberikan informasi tambahan seperti memberikan testimoni, yang mana hal tersebut mempunyai peran yang besar untuk mendapatkan kepercayaan dari pelanggan sehingga bisa menunjukan kepuasan pelanggan lain terhadap produk yang kita jual. Kemudian terkait pentingnya kepercayaan, adapun dari masalah pembayaran juga menjadi faktor yang dapat mempengaruhi kepercayaan. Di sisi lain ada ketepatan waktu pengiriman barang, apabila terjadi suatu masalah maka jelaskan apa yang menjadi kendala dalam pengiriman kepada pelanggan agar nantinya tidak menimbulkan suatu kekecewaan. Pelaku bisnis juga harus menguasi kriteria produk yang dijual, yang mana dapat mempengaruhi pentingnya suatu kepercayaan. Apabila pelaku bisnis tidak menguasi produk yang dijual maka dapat mempengaruhi proses pengambilan keputusan pembelian dari pelanggan. Selain pentingnya kepercayaan yang perlu ditumbuhkan, kejujuran juga perlu diterapkan baik dari pelaku bisnis maupun dari pelanggannya. Kejujuran menjadi dasar dalam melakukan bisnis terkait produk yang dijual, kendala pada saat pengiriman produk dan lain sebagainya.

Berdasarkan uraian yang telah diuraikan sebelumnya, temuan penelitian ini dinamakan sukses berwirausaha yang dituangkan dalam gambar 1 .

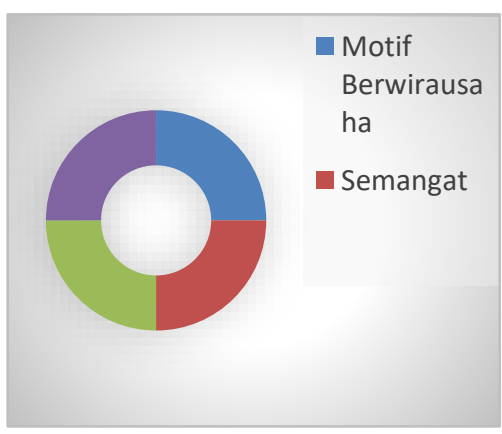

\section{Gambar 1. Temuan penelitian}

Berdasarkan gambar 1, dapat dikatakan bahwa seseorang dikatakan sukses dalam berwirausaha apabila memiliki motif dalam menjalankan usaha, adanya semangat untuk mengembangkan usaha, selalu mencari dan menemukan hal-hal yang baru untuk kelanjutan usahanya, serta yang tidak kalah pentingnya adalah selalu menjaga kepercayaan dan kejujuran dalam menjalankan usahanya. Empat aspek tersebut saling bersinergi, sehingga menjadi satu kesatuan yang merupakan kunci sukses seseorang dalam berwirausaha. 


\section{SIMPULAN}

Berdasarkan pengalaman para pelaku bisnis dalam kajian ini dapat disimpulkan bahwa kemajuan teknologi saat ini telah mendorong berbagai kalangan untuk menjalankan bisnis online. Ketertarikan seseorang terhadap bisnis ini dikarenakan tidak membutuhkan modal yang besar, adanya keluwesan waktu dan tempat dalam menjalankan bisnis, serta kemudahan dalam memasarkan produk. Seseorang dikatakan sukses berwirausaha apabila dapat menyatukan berbagai aspek yang dibutuhkan seperti motif, semangat, inovasi, dan kepercayaan, serta kejujuran.

Hasil penelitian ini diharapkan dapat berimplikasi pada teori yang berkaitan dengan kewirausahaan, selain itu dapat dijadikan rujukan bagi pebisnis pemula untuk mengembangkan usahanya. Peneliti menyadari bahwa masih banyak yang perlu dikembangkan dan dikaji lebih lanjut untuk penelitian ini, tetapi dalam kajian ini hanya sebatas mengungkap apa yang dilakukan para pebisnis online dalam menjalankan usahanya. Masih banyak yang dapat dikaji lebih lanjut dari topik ini seperti, sistem bagi hasil khususnya bagi reseller, dan kedudukan dropshipper dipandang dari sudut syariah.

\section{REFERENCES}

Amal, S. (2019). Metode Bracketing Edmun Husserl. Dialektika: Jurnal Pemikiran Islam Dan Ilmu Sosial 12(1), 77-87.

Anggraini, R. Y. (2017). Masuknya Paradigma Interpretif Pada Kajian Ilmu Akuntansi. Jurnal Analisa Akuntansi dan Perpajakan, 1(1), 51-62.

Arfiansyah, S. (2016). Eksplorasi Makna Partisipasi Masyarakat dalam Penganggaran. Jurnal Akuntansi Aktual, 3(4), 261-271.

Asih, I. D. (2005). Fenomenologi Husserl: Sebuah Cara "Kembali Ke Fenomena". Jurnal Keperawatan Indonesia, 9(2), 75-80.

Baktiono, R. A., dan Artaya, I. P. (2016). Memilih Media Sosial Sebagai Sarana Bisnis Online Melalui Pendekatan Uji Categorical. EJurnal Manajemen Kinerja, 2(2), 1-10.

Berek, D. I. P. (2014). Fashion sebagai Komunikasi Identitas Sub Budaya (Kajian Fenomenologis Terhadap Komunitas Street Punk Semarang), Interaksi: Jurnal Ilmu Komunikasi, 3(1), 56-66.

Creswell, J. (2015). Riset Pendidikan Perencanaan, Pelaksanaam, dan Evaluasi Riset Kualitatif $\mathcal{E}$ Kuantitatif (Edisi ke-5). Yogyakarta:
Pustaka Pelajar.

Dahlan, M. (2010). Pemikiran Fenomenologi Edmund Husserl dan Aplikasinya dalam Dunia Sains dan Studi Agama. Salam: Jurnal Studi Masyarakat Islam, 13(1), 21-32.

Dwiyoso, H., Susanto, M. H., dan Kaluge, D. (2008). Analisis Fenomenologi Bank Mendirikan Koperasi Kredit. Journal Of Indonesian Applied Economics, 2(1), 1-21.

Farida, W. M. (2017). Mengungkap Pemahaman Peran Akuntan Pendidik: Studi Fenomenologi. Jurnal Reviu Akuntansi dan Keuangan, 7(2), 1055-1066.

Fitria, T. N. (2017). Bisnis Jual Beli Online (Online Shop) dalam Hukum Islam Dan Hukum Negara. Jurnal Ilmiah Ekonomi Islam, 3(1), 52-62.

Harisno, dan Pujadi, T. (2009). E-Business dan ECommerce sebagai Trend Taktik Baru Perusahaan. Commit, 3(2), 66-69.

Hasanah, U. (2013). Sistem Penjualan On_Line Pada Toko Kreatif Suncom Pacitan. Indonesian Journal Of Network \& Security, 2(4), 40-48.

Hasbiansyah, O. (2008). Pendekatan Fenomenologi: Pengantar Praktik Penelitian dalam Ilmu Sosial dan Komunikasi. Mediator, 9(1), 163180.

Hidayaha, N. A., Kumaladewi, N., dan Efryllac, S. (2010). Sistem Informasi Pemesanan Tiket Pesawat Berbasis Web Pada Bana Tour. Jurnal Sistem Informasi, 3(1), 1-6.

Irianto, G., dan Subandi. (2015). Studi Fenomenologis Kebahagiaan Guru di Papua. Gadjah Mada Journal Of Psychology, 1(3), 140-166.

Kamayanti, A. (2016). Metodologi Penelitian Kualitatif Akuntansi: Pengantar Religiositas Keilmuan. Jakarta: Yayasan Rumah Peneleh.

Morgan, G. (1988). Accounting as Reality Construction: Towards a New Epistemology for Accounting Practice. Accounting, Organizations and Society, 13(5), 477-485.

Muslim. (2015). Varian-Varian Paradigma, Pendekatan, Metode, dan Jenis Penelitian dalam Ilmu Komunikasi. Wahana, 1(10), 7785.

Nasution, A., dan Baidawi, T. (2016). Sistem Informasi Penjualan Obat Berbasis Web Pada Apotek Perwira Jaya Bekasi. Informatics for Educators and Professionals, 1(1), 70-83.

Pane, E. S., dan Sadar, M. (2015). Sistem Informasi Penjualan Boneka Berbasis Web. Teknologi 
Informasi \& Komunikasi Digital Zone, 6(1), 25-33.

Putri, I. G., dan Masykur, A. M. (2017). Bertahan dalam Dilema (Studi Fenomenologis Menghadapi Stres Kerja pada Psikolog Klinis Wanita). Jurnal Empati, 6(1), 239-245.

Qomaruddin, M., Sudradjat, A., dan Sopandi, R. (2018). Sistem Informasi Penjualan Batik Berbasis Web Pada Toko 10s Pasar Grosir Setono. Publikasi Jurnal \& Penelitian Teknik Informatika, 2(2), 105-111.

Rachman, B. M. (2013). Fenomenologi Diri dan Konstruksi Sosial Mengenai Kebudayaan: Edmund Husserl dan Jejak-Jejaknya pada Maurice Merleau-Ponty dan Peter Berger. Ilmu Ushuluddin, 1(6), 493-514.

Salviana, V. (2009). Pendekatan Interpretif dalam Ilmu-Ilmu Sosial. Salam: Jurnal Studi Masyarakat Islam, 12(2), 1-13.

Sawarjuwono, T. 2005. Bahasa Akuntansi Dalam Praktik: Sebuah Critical Accounting Study. Jurnal Telaah Ilmu Akuntansi, 6(2), 89-110.

Sanders, P. (2001). Phenomenology: A New Way of Viewing Organizational Research. The Academy of Management Review, 7(3), 353-360.

Starks, H., dan Trinidad, S. B. (2007). Choose Your Method: A Comparison Of Phenomenology, Discourse Analysis, And Grounded Theory. Qualitative Health Research, 17(10), 1372-1380.

Sudarsyah, A. (2013). Kerangka Analisis Data Fenomenologi (Contoh Analisis Teks Sebuah Catatan Harian). Jurnal Penelitian Pendidikan, 13(1), 21-27.

Syadzwina, A. W. W., Akbar, M.., dan Bahfiarti, T. (2014). Fenomenologi Perilaku Komunikasi Suporter Fanatik Sepakbola dalam Memberikan Dukungan pada PSM Makassar. Jurnal Komunikasi Kareba, 3(1), 1-7.

Toni, A., dan Lestari, R. (2013). Paradigmatis Fenomenologi dalam Ilmu Komunikasi (Studi Konstruksi Makna Realitas Media dan Komunikasi). Jurnal Semiotika, 7(1), 1-19.

Yuliana, O. Y. (2000). Penggunaan Teknologi Internet dalam Bisnis. Akuntansi \& Keuangan, 2(1), 36-52. 